DOI https://doi.org/10.18551/rjoas.2017-12.36

\title{
SUPPLY CHAIN MANAGEMENT OF IMPORTED FROZEN BEEF: AN ALTERNATIVE TO INTEGRATE WITH LOCAL BEEF SUPPLY CHAIN MANAGEMENT
}

\author{
Sani Rakhmat*, Arifin Zainul, Abdillah Yusri \\ Postgraduate Program of Business Administration, Faculty of Administrative Science, \\ University of Brawijaya, Indonesia \\ *E-mail: sani.rakhmat@gmail.com
}

\begin{abstract}
The purpose of this study is to describe the supply chain management of imported frozen beef from Australia to Indonesia; to analyze where the strengths, weaknesses, opportunities, and threats for the frozen meat distributor, and what strategy should be chosen; and to analyze alternatives of cooperation between imported frozen beef distribution with local beef distribution chain. The research approach is qualitative, and the research strategy is a case study. This research was conducted in Jakarta, data collecting technique by interview method and literature study. Data analysis techniques use supply chain management (SCM) and strengths, weaknesses, opportunities, and threats (SWOT) analysis. The results show that the distribution chain management of imported frozen beef needs to tripartite cooperation with government and local beef distributors to conduct joint marketing of imported frozen beef and cooler procurement to the point of retailers in traditional markets; expanding the market share of imported frozen beef to industrial segments (hotels, restaurant, catering company; and meat processing factories); and cooperate with imported beef suppliers to overcome the problem of taste flavor and lack of weight of imported frozen meat, and clarify halal certification.
\end{abstract}

\section{KEY WORDS}

Imported frozen beef distributor, local beef distributor, supply chain management, SWOT analysis.

Beef price in Indonesia especially started from 20015 is known expensive. In 20102011 local beef price ranges between Rp 45.000 (US\$ 3.32) - Rp 55.000 (US\$ 4.06) per kilogram. At that time World Bank has proposed that beef price in Indonesia is relatively expensive. World Bank compares beef price in Indonesia per December 2012 on average reaches up to US\$ 9.76, while in Malaysia it is only up to US\$ 4.3, and US\$ 4.2 in Thailand (Permana, 2013). In 2016, beef price in Indonesia reaches up to Rp 120.000- Rp 130.000 per kilogram, which means beef price increase is more than $100 \%$ only in four years. Beef price since 2015 is almost never decreased until 2017.

The reason why beef price in Indonesia is too expensive is that demand and supply imbalance. There is a demand and supply imbalance of beef and buffalo meat. The average growth of beef and buffalo meat demand during 2015-2019 is 6.71 percent. This growth of demand is caused by population growth, living cost index, Gross National Product (GNP) per capita, and society's purchasing power as well. The problem is that the growth demand for beef and buffalo meat is not balanced with the average supply for the same period (20152019) that is only 3.08 percent. That is why almost every year Indonesia experiences a deficit in determining the needs of beef and buffalo meat which is in 2019 projected deficit of 143.63 million tons (National Development Planning Body or Bappenas, 2013).

In terms of fulfilling beef supply, the production capacity of local beef, according to the Indonesian Animal Protein Business Association (APPHI) per 2014, is just contributing around $67 \%$ from the total of national beef needs. The needs of beef surely fluctuate, but it tends to increase in the last five years. In order to need the lack of beef $(27 \%)$, Indonesia meets it through import quota, especially from Australia and New Zealand. 
So far Indonesian government assumes that Supply Chain Management (SCM) of local beef in Indonesia is not efficient so that beef price will be expensive. In Indonesia, there are three supply chains of local beef, namely: supply chain of cattle and local beef, the supply chain of cattle and imported beef, and supply chain of imported frozen beef. One of the government ways to overcome an alternative of beef supply and also expected can push beef price is increasing the number of imported frozen beef supply. Imported frozen beef is expected able to give an alternative to the society so is able to choose the product of beef in accordance with the taste and the purchasing power. Imported frozen beef is made as a tool to press beef price because it is only Rp 80.000 per kilogram or only $61.5 \%$ to $67 \%$ from the local beef price.

Government policy to intervene beef market with imported frozen beef massively begunn in 2015-2016 is actually not successful to decrease local beef price. Local beef price is stable at IDR 120,000 - IDR 130,000 per kilogram, even in a local area it reaches up to IDR 135,000 per kilogram. Why is imported frozen beef price not successful to press local beef price? There are many answers to that question. If seen from supply chain management of imported beef, it is obvious that imported frozen beef cannot get maximally into the traditional market that along this time becomes the end of the point of local beef sells for public consumer or individual consumer.

Having been seen from supply chain management, imported frozen beef is largest ordered from Australia, New Zealand, and other countries. The frozen beef importer is 62 beef importer companies that are parties to Indonesian Meat Importers Association (Aspidi). That imported frozen beef is divided into two classes. Prime cut imported frozen beef is distributed to the star rated hotel and supermarket. Supermarket sells fresh meat to the restaurant/catering company and sells the processed products to the consumer. Second class meat sold to the industry of meat processing belonging to the organization of National Meat Processor Association (NAMPA) results in sausage, smoked beef, burger, and etc. These processed products are then sold in a supermarket. In particular for imported frozen beef, until 2015 government policy prohibits the distribution chain from entering traditional markets to not compete and deal with local beef (Bappenas, 2013).

Interestingly, given the supply chain of imported frozen beef that is different from the supply chain of local beef or imported dairy chains, there are difficulties for the entrepreneurs and distributors of imported frozen beef to make frozen beef as an alternative to local beef. In the market, the imported frozen beef distribution system cannot collaborate with the local beef SCM. In the markets, fresh beef SCM does not absorb or adopt frozen beef.

The impact of no collaboration between imported frozen beef supply chain and fresh beef supply chains is that the imported frozen beef distributors must make their own SCM, starting from importing the frozen beef (in this case is from Australia), but especially when distributing it until the end user. As a result, SCM dualism in marketing between fresh beef and frozen beef distribution channels happens not only in the upstream but also downstream to the final distribution point that meets the final consumer.

There is a plain difference between imported frozen beef and fresh beef marketing. The distribution of imported frozen beef creates its own path in the final market. In a number of ends markets found box truck selling imported frozen beef. Moreover, the distribution chain of state-owned enterprises uses various government channels, including the police sector. Those police sectors are involved not in terms of security, but in case of distribution, i.e. being used as an outlet distribution of imported frozen beef.

Supply chain separation of imported frozen beef and local beef, as it has been done in Lebaran (annual tradition of Idul Fitri) 2016 proved to make the supply chain of imported frozen beef less to end-user in traditional markets. The implication is that most people still buy local beef even the price is expensive. The government's intention to make imported frozen beef whose price is relative cheap to be an alternative for society in selecting meat specifications at their respective prices is ineffective. The issue of high beef prices remains unresolved.

According to the background of the problem, it can be seen that the obstacle of the achievement of cheap beef price is not in the absence of cheap beef supply (imported frozen 
beef), but because of imported beef supply chain problems not reaching end-user effectively, which is different from local beef supply chain that more effective hits the end-users. For that matter, it is interesting to examine how the supply chain management of imported frozen beef can effectively reach the end-user. One of the SCM strategies to get effectively to the end user is by working with local beef SCM. Supply chain cooperation can be implemented primarily at the last distribution point, i.e. in traditional markets. This study focuses on the issue of how distribution chain management organized by imported frozen beef distributors allows collaborating with the local beef distribution chain so that the imported frozen beef distribution chain can be effective to the end user.

\section{LITERATURE REVIEW}

Effective Distribution. Effective distribution starts with an effective supply chain. The value chain stages, according to Chopra and Meindl (Sreenivas \& Srinivas, 2008) value chains consist of all stages that are directly or indirectly involved in meeting customer demands, consisting of five stages of the value chain: (i) components/raw materials, (ii) producers, (iii) wholesalers and distributors, (iv) retailers, (v) customers. Meanwhile, Keskinock and Tayur (in Sreenivas \& Srinivas, 2008) argue that the main goal of supply chain management is to deliver the right product in the right time while keeping cost-efficient in an efficient manner. They identify three components of supply chain management, namely procurement, manufacture and distribution, and disposable inventory items. Lummus and Vokurka (1999) develop a supply chain understanding compiled from many authors. They claim that the supply chain consists of all activities involved in delivering products and raw materials to customers, including distribution channels, delivery of goods to customers, and information systems needed to monitor all of these activities.

In the distribution network planning, there is an established relationship between the number of distribution points, transportation costs, and customer service targets. In a graphical sense, the point of those three items are will be an optimal balance of facilities and transportation costs for building with low cost and distribution networks. Typically distribution networks tend to be centralized, so they can take advantage of internal support structures such as facility management, entry order, consumer utilities, and data processing. Depending on the level of centralization, it can generally save $50 \%$ or more of the distribution cost, compared to costs if the distribution is decentralized. Of course, service levels, limitations on available facility size, risk mitigation during peak loads, that all should be accounted as a factor in the decision matrix (Sreenivas \& Srinivas, 2008).

Six Stage of Value Chain. The purpose of the value chain analysis (VCA) is to improve supply chain performance. Therefore the requirements to be met are the understanding of the product flows, information flow (information flowes), as well as management and control in the value chain. In this context, VCA is a diagnostic tool used to assist management decisions and produce recommendations for improved value chain. Previous studies have added and perfected the early stages of VCA, i.e. the step of 1, 3, and 4 in Figure 1, by adding consumer research to reflect a focus on consumer needs and wants. The VCA approach has been expanded and developed to deal with varied situations. In the agribusiness value chain, VCA has been developed into six stages (Howieson et al. 2016) (see Figure 1).

Engaging the chain. The first and fundamental stage of engagement into chains will determine how chain member interacts as a whole through the VCA process. This first stage is supported by the six researchers as shown in Table 1. The six researchers highlight the importance of gaining commitment regarding all processes of all chain members, including senior management to ensure success. In general, many chain members have never had previous cooperation, then team building is considered important for VCA success. If previously members of the chain have worked together, then this is a good indicator of the success of the next period value chain. VCA project is an effective way to begin the process of translating the partnership concept of desire into reality, even before there has been hostility between them (Howieson et al., 2016). 


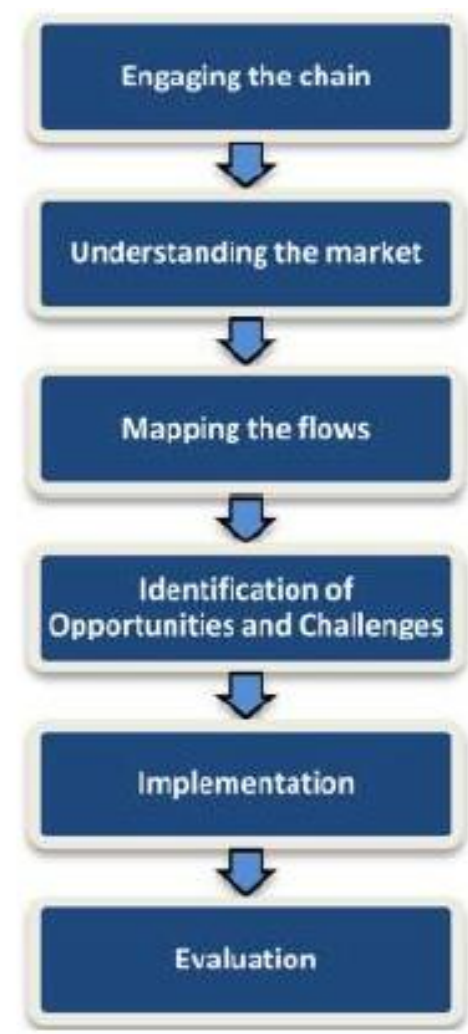

Figure 1 - Six VCA Stages Broaden Source: Howieson et al. (2016)

Those six stages of VCA developed are the result of the synthesis of six researchers, as presented in Table 1.

Table 1 - VCA Synthesis of Six Researchers

\begin{tabular}{|l|l|l|l|l|l|l|}
\hline \multicolumn{1}{|c|}{ Stage } & $\begin{array}{l}\text { Taylor } \\
(2005)\end{array}$ & $\begin{array}{l}\text { Francis } \\
\text { et al. (2008) }\end{array}$ & $\begin{array}{c}\text { Fearne } \\
(2009)\end{array}$ & $\begin{array}{c}\text { Bonney } \\
\text { et al. (2009) }\end{array}$ & $\begin{array}{c}\text { Soosay } \\
\text { et al. (2012) }\end{array}$ & $\begin{array}{c}\text { Howieson } \\
\text { et al. (2016) }\end{array}$ \\
\hline 1.Engage the chain & $\checkmark$ & $\checkmark$ & $\checkmark$ & $\checkmark$ & $\checkmark$ & $\checkmark$ \\
\hline $\begin{array}{l}\text { 2.Understanding the } \\
\text { market }\end{array}$ & X & X & $\checkmark$ & $\checkmark$ & $\checkmark$ & $\checkmark$ \\
\hline 3.Mapping the flows & $\checkmark$ & $\checkmark$ & $\checkmark$ & $\checkmark$ & $\checkmark$ & $\checkmark$ \\
\hline $\begin{array}{l}\text { 4. Identify opportunities } \\
\text { and challenges }\end{array}$ & $\checkmark$ & $\checkmark$ & $\checkmark$ & $\checkmark$ & $\checkmark$ & $\checkmark$ \\
\hline 5. Implementation & X & X & X & $\checkmark$ & X & $\checkmark$ \\
\hline 6. Evaluation & X & X & X & X & X & $\checkmark$ \\
\hline
\end{tabular}

Source: Howieson et al. (2016).

Understanding the market. The importance of end users is recognized in the VCA process in the second phase of the VCA, which understands the market. Studies have shifted from being more focused on production into the direction to understand consumer utility as central in the value chain process. To create a value in a chain, it is necessary for the industry to understand what consumer values are in a product or service so that the industry adjusts its business to those consumer values. Although consumer values were known more than 25 years ago, they were recently adopted by the industry of agri-food (Bonney et al., 2009; Fearne, 2009; Griffiths et al., 2000; Zokaei and Hines, 2007; Lummus and Vokurka, 1999; Stevens, 1989; Cooper and Ellram, 1993).

Mapping the flows. The mapping of the value chain is one of the fundamental components of the VCA. This mapping allows identification that includes three elements, namely: (i) the flow of products (ut2), (ii) information, and (iii) relationships. The data required as a material for mapping the flow of supply can be obtained by interviewing supply chain 
members from the point of production to the point of sale. The mapping data is related to the information on planning, estimating/predicting, ordering, production, distribution, marketing, and services for customers. This data informs the flow of products and information on the chain, and further data are needed to inform flow relationships, including stakeholder meetings and workshops. The flow of products requires the physical flow of beef through the value chain. It aims to coordinate the correct delivery volume and qualification of beef according to the order of the consumers. Data mismatch in the agri-foods chain between supply and demand causes excessive supply or vice versa on the chain. Those two situations drain unnecessary costs on firms and limit the chains to create value. The information flow is a two-way process in the value chain. The information of end consumers (i,e. preference, specification and quality demand) can be transferred back along the chain to the producer, which then the producer can tell the market about the issue the market needs to know. In practice, this transfer of knowledge allows the company to become more competitive. The flow of relationship describes how members of the chain relate to each other. This relationship offers the possibility of all parties, through coordination and joint optimization through values sharing and works for identifying further opportunities (Howieson et al., 2016).

Identification of Opportunities and Challenges. The identification of opportunities and challenges proved to be the highlight of the VCA process. After going through 1-3 chain processes, the company can inventory a number of strategies related to their respective opportunities and challenges. The group of entrepreneurs belonging to the chain must choose one strategy implemented by the entrepreneurs from those strategies (Howieson et al., 2016).

Implementation. The four stages above are data collection, identification of opportunities and challenges, and other things that are conceptual. That all have to implemented consistently and in discipline way by all members of supply chain (Howieson et al., 2016)

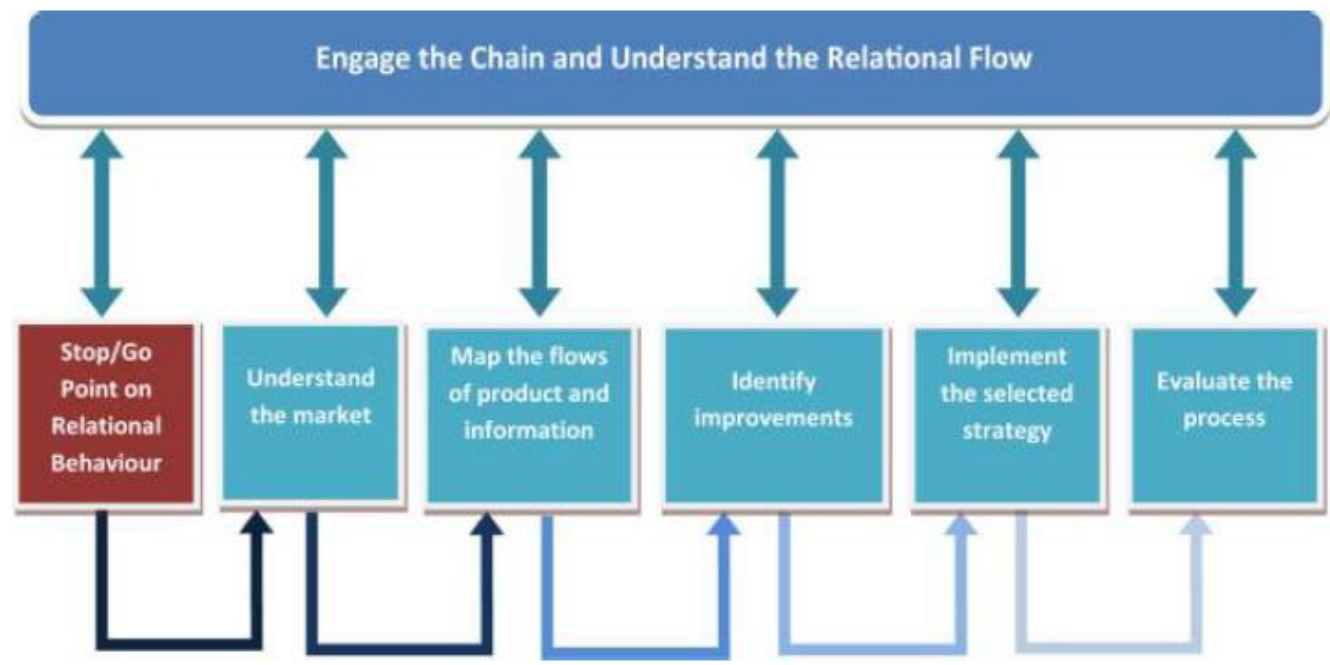

Figure 2 - Analysis Approach Modification of Value Chain Source: Howieson et al. (2016).

Evaluation. The last step of VCA process is evaluating strategy performance of value chain chosen. This evaluation uses a number of methods. The result of the evaluation is various, started from the need of sale improvement after using the strategy chosen, or sales improvement is not improved yet but there has been awareness between the actors of the value chain. The result of evaluation also reveals not-good-yet result so needs a research why it fails and how the solution. This evaluation also concerns the level of results acceptance by each value chain actor who may have different perceptions of the result (Howieson et al., 2016). 
SWOT Analysis. SWOT which is one of the few strategic planning tools used by businesses and other organizations to ensure that there are clear objectives defined for the project or business, and that all factors related to such efforts, whether positive or negative, are identified to accomplish the task, the process involves four areas of consideration: strengths, weaknesses, opportunities, and threats. It should be noted that, when identifying and classifying relevant factors, the focus is not only on internal issues but also on external components that may affect project success (Osita et al., \{Ut2\} 2014).

According to Rangkuti (2013), the method of data analysis using SWOT analysis has following stages:

1. The SWOT questionnaire filling stage consists of two parts, namely the section to assess the current state of the four elements (strengths, weaknesses, opportunities, and threats); and the second is a section to assess the degree of urgency handling.

2. Creating an Internal Factor Evaluation (IFE) matrix to analyze internal environmental factors. Through the IFE, matrix we will get the weighted value for each item as well as for the total weighted item for IFE.

3. Creating an External Factor Evaluation (EFE) matrix to analyze external environmental factors. Through the EFE matrix, we get a weighted value for each item as well as for the total weighted item for EFE.

4. Creating a joint matrix of IFE and EFE (Internal-External), so that will know the position of supply chain quadrant for an importer of frozen beef for now. This InternalExternal Quadrant consists of nine, which is the matrix between liquidation, shrinking, stability, growth.

5. Creating a SWOT matrix, with composition: SO Strategy (Strengths-Opportunities), ST Strategy (Strengths-Threats), WO Strategy (Weaknesses-Opportunities), and WT Strategy (Weaknesses-Threats).

6. Creating a Quantitative Strategic Planning (QSPM) Matrix analysis to generate alternative strategies.

\section{METHODS OF RESEARCH}

The approach of this research is qualitative with case study research strategy. A case is bound by time and activity, in addition, the researcher collects data in detail using various data collection procedures and in a continuous time (Sugiyono, 2013). The research was conducted in Jakarta, especially in two beef associations in Indonesia, i.e. Indonesian Meat Producers and Feedlot Association (Apfindo) mobilizing local beef producers, and Indonesian Meat Importers Association (Aspidi) mobilizing imported beef companies and frozen beef. In terms of data collection techniques, primary data were obtained in the form of in-depth interviews, questionnaires of Strengths, Weaknesses, Opportunities, and Threat (SWOT) as well as observation. Data that have been collected by researchers then processed. The secondary data is literature study. Supply chain management (SCM) model is used to analyze the data to answer the first and third item research questions, and analysis SWOT to answer the second question.

\section{RESULTS AND DISCUSSION}

Based on RPJMN 2015-2019 the national beef production sources are: (i) local beef, consisting of beef cattle, dairy bull, and dairy cow, which most them are beef cattle; (ii) feeder steer imported from Australia and fattened in Indonesia for about 100 days; (iii) imported frozen beef (Bappenas, 2013).

The business structure of beef cattle rearing in Indonesia consists of two types of business, namely breeding and fattening/finishing. The breeding effort is semi-intensive and extensive. Semi-intensive breeding efforts consist of natural mating and artificial insemination (IB). Natural mating uses the same cow (Bali cattle, Madura cattle, ongole-cross-breed cattle, Sumba ongole, and other local cows). The process of natural mating is much happening outside Java. In the meantime, breeding with artificial insemination utilizes superior cattle 
cement of foreign cattle (Limousin, Simmental, Carolais, and Brahman) whose breed cattle can achieve greater life weight, and many occur in Java (Bappenas, 2003).

The Indonesian government has so far integrated the supply chain of imported feeder cattle and with local cattle production, i.e. in the short-term intensive fattening program (3 months/cycle). This effort is done by (feedlotter for commercial purposes and may occur in Lampung. Feeder cattle for fattening are imported from Australia in a very fast time (1-2 weeks) and with a large amount (2,000-3,000 heads) once transported to Indonesia. This business cycle is very short, which is about 150 days for farmers, and 9-100 days or even less for feedlot. The integration of local imports and production has so far been regarded as a promising effort for Indonesia to be self-sufficient in beef (Bappenas, 2003).

Until 2012, there is still a segment segregation of imported frozen beef allocated to meat, hotel, and restaurant and catering industry. In 2015 the segment of frozen beef is allowed to enter the general consumer segment, especially through traditional markets. Since 2015, the imported frozen beef distributor has faced two buyer segments, i.e. industry segment and general consumer segment. For the supply chain to the industry segment, the imported frozen beef distributor has been relatively well established. Meanwhile, their distribution chain to the general consumer segment through traditional markets is still very weak and faced with a chain of local beef distributions that have existed for decades.

Based on SWOT analysis and QSP matrix or Quantitative Strategic Planning Matrix (QSPM), it gets a recommendation of three strategies that can be implemented. Those three strategic recommendations are; (i) Strategy 1: Conducting tripartite cooperation (i.e. government, imported frozen beef distributor, and local beef distributor) to conduct joint marketing of imported frozen beef and procuring refrigeration equipment to the point of retailers in traditional market; (ii) Strategy 2: Expanding market share of imported frozen beef to industrial segments (hotels, meat processing company); (iii) Strategy 3: Working closely with imported beef suppliers to overcome the problem of taste (taste) and lack of weight of imported frozen beef.

The problem faced by the imported frozen meat distributor is not in the supply aspect, because from the supply side so far there are no significant constraints. The main problem of distributors is how their import goods can reach the end users in a massive and smooth manner. Based on the calculation of effectiveness and efficiency, the best option is cooperation. Cooperation between local meat distributors, feeder cattle, and imported frozen beef, which is mediated by the government. There are a number of technical aspects to be considered in the cooperation, among others, the issue of refrigeration equipment, electrical problems (energy) for refrigeration equipment, the problem of cooperative transcription system recommended by consignment system; as well as the problem of three major issues (halal slaughter, reduced scales, and the taste and aroma of frozen beef that is not appeared).

\section{CONCLUSION AND SUGGESTIONS}

According to the research results and related to the research purpose, it can be concluded that the distribution chain of frozen beef importers to the general consumer segment through traditional markets, is still very weak and should face local beef distribution chain that has existed for decades. The need for synergy (cooperation) between the producers, distributor and government, as such the constraints occurred can be resolved.

Theoretically or academically, the theme of this future research should be carried out with a mixed methods approach, combining quantitative and qualitative approaches, so that the elements of accuracy and mutual discussion are mutually supportive.

Practically, the government or the association of local beef, feeder cattle, and imported frozen beef should make decisions with more accurate data.

The government should pioneer the occurrence of this distribution cooperation, especially at the final distribution level. This way is expected to more widely spread of imported frozen beef products, so that sooner or later it will affect the amount of supply, and will lower the price of beef as a whole. 


\section{REFERENCES}

1. Badan Perencanaan Pembangunan Nasional/ BAPPENAS. (2013). "Studi Pendahuluan Rencana Pembangunan Jangka Menengah Nasional (RPJMN) Bidang Pangan dan Pertanian 2015-2019."

2. Bonney, L., Clark, R., Collins, R and Fearne, A. (2007). "From serendipity to Sustainable competitive Advantage: Insights from Houston's Farm and their journey of co-innovation". Supply Chain Management: An International Journal, 12 (6), pp. 395-399.

3. Bonney, L., Clark, R., Collins, R., Dent, B. and Fearne, A. (2009). "Sustainable Value Chain Analysis: An Agri-Food Chain Diagnostic. University of Tasmania, Kent Business School and The University of Queensland. Queensland.

4. Cooper, M. and Ellram, L. (1993). "Characteristics of supply chain management and the implications for purchasing and logistics strategy". The International Journal of Logistics Management, 4 (2), pp. 13-24.

5. Fearne, Andrew.(2009). "Sustainable Food and Wine Value Chains. Government of South Australia. Adelaide.

6. Griffiths, J., James, R and Kempson, J. (2000). "Focusing customer through manufacturing supply chains by the use of customer focused cells: an appraisal". International Journal of Production Economics, 65 (1), pp. 111-120.

7. Howieson, J., Lawley, M., \& Hastings, K. (2016). "Value chain analysis: an iterative and relational approach for agri-food chains," Supply Chain Management: An International Journal, 21(5), pp. 352-362.

8. Lummus, R. (1999). "Defining supply chain management: a historical perspective and practical guidelines". Industrial Management \& Data Systems, 99 (1), pp. 11-17.

9. Osita, Ifediora C. (2014). "Organization's stability and productivity: the role of SWOT analysis an acronym for strength, weakness, opportunities and threat". International Journal of Innovative and Applied Research, 2 (9), pp. 23-32.

10. Permana, Sony Hendra. (2013). "Instrumen pengendalian harga daging sapi" Info Singkat, V (14/II/P3DI/juli), pp. 13-16.

11. Rangkuti, F. (2013). Analisis SWOT. Jakarta: PT Gramedia Pustaka Utama.

12. Soosay, Claudine, Andrew Fearne and Benjamin Dent. (2012). "Sustainable value chain anlysis - a case sztudy of Oxford landing from vine to dine," Supply Chain Management: An International Journal, 17(1), pp. 68-77.

13. Sreenivas, M \& Srinivas, T. (2008). "Effectiveness of Distribution Network". International Journal of InformationSystems and Supply Chain Management. Vol 1 (1), pp. 80-86.

14. Stevens, G. (1989). "Integrating the supply chain". International Journal of Physical Distribution \& Materials Management, Vol. 19 No. 8, pp. 3-8.

15. Sugiyono. (2013). Metode Penelitian Kombinasi (Mixed Methods). Bandung: Alfabeta.

16. Taylor, D.H. (2005). "Supply Chain Analysis: An Approach to Value Chain Improvement in Agri-Food Chains". The International Journal of Physical Distribution and Logistics Management, 35 (10), pp. 744-761.

17. Zokaei, K. and Hines, P. (2007). "Achieving consumer focus in supply chains". International Journal of Physical Distribution \& Logistics Management, vol. 37 No. 3, pp. 223-247. 